\title{
Innovation or Renovation? The Management of Strategic and Adoption Decisions within a University
}

\author{
Arthur Tatnall and Karen Manning \\ Graduate School of Business, and School of Management and Information Systems, \\ Victoria University, Australia
}

\begin{abstract}
Most universities make use of e-learning facilities to manage on-line learning, and this paper questions how decision are made to adopt this e-learning package rather than that one, and then how to make use of it. We suggest that educational technology adoption decisions are made at two levels: strategic decisions are made by the university to implement a particular package, and then individual academics made adoption decisions regarding those aspects of the package they will use in their teaching and how they will use them. In the paper we suggest that such technology should be regarded as an innovation and viewed through the lens of innovation adoption theory. We argue that analysis of these adoption decisions needs to be framed differently at each level, using an approach that is appropriate to that level.
\end{abstract}

Keywords: Management of e-learning, innovation theory, technology adoption, strategic decision making, actor-network theory.

\section{Adoption and Use of e-Learning Technologies in a University}

An Australian University, we will call it Albert University, made a strategic decision some years ago to adopt WebCT as its e-Learning platform. As most academics will know, the WebCT e-learning platform offers a number of facilities for the management of e-learning, including: discussion boards, an e-mail system, live chat, and the support of content including documents and web pages. The extent to which each of these facilities have been adopted and used varies from university to university and academic to academic.

Blackboard Inc, the company that owns the WebCT product, has indicated that they will soon withdraw support for it in favour of their main product: Blackboard. This will necessitate Albert University making another strategic decision: should the university adopt Blackboard or move to an open source product such as Moodle? While the decision to purchase and implement a particular e-Learning product by the university is a strategic one, this decision does not necessarily determine the extent to which each individual academic will make use of it in their teaching. In the case of Albert University, while there was a general policy requiring each subject to use WebCT, decisions on how to make use of it in their own teaching subjects have been left up to the academic co-ordinating each subject. While the overall adoption 
decision by the university should be considered in terms of strategy, individual adoption decisions to use some aspects of the package but not others are best considered thought the lens of innovation adoption.

In summary, at Albert University the adoption, implementation and use of an elearning package involved a number of decisions, made at two different levels: the university level and the level of the individual academic.

1. The initial strategic decision by the university to adopt WebCT as an elearning platform - this should be considered in terms of strategic decision making.

2. A decision by individual academic staff on how they will use WebCT in their teaching, or whether they will adopt it as an e-learning environment at all this should be considered in terms of innovation adoption.

3. Another strategic decision to be made by Albert University to adopt a new elearning platform as a replacement for WebCT.

4. An innovation adoption decision by academic staff on how they will use this new e-learning platform, or whether they will adopt it at all.

This paper investigates the strategies and innovation factors behind all these adoption decisions -strategic decisions made by the university administration and adoption decisions made by individual academic staff members. Following the university adoption decisions, we will consider whether complete adoption of this technology by individual academics necessarily follows.

\section{Strategy for the Adoption of Technological Innovations}

At the conceptual level strategic management is a process for co-ordinating decision making in what may be large, diversified organisations. Hanson et al. (2008) describe strategic management as the process of making and implementing strategic decisions. In this approach tactics and strategy are often distinguished: tactics being seen as short term adaptive actions while strategic decisions determine the overall direction of the organisation. The problem is that strategic decisions are made at all levels of the organisation and not always recognised as significant at that time (Boxall and Purcell, 2003). In other words, a decision can be either a planned activity or a series of events, which lead to a desirable objective. Deliberative strategy is consciously formulated while emergent strategy results from incremental decisions emergent through networks of actors (Latour 1996).

Many business texts concentrate on systematic planning and indeed these models have dominated consultants' prescriptions for both private and public organisations. The fact that many organisations do not systematically plan, or fail to implement plans leads to the adaptive type of models. Often strategies are formulated but not implemented because these cut across organisation units, information is inadequate and the control imposed by planning actually inhibits innovation and decision making. This leads to an understanding that the notion of strategy is not neutral. How it is defined and used in an organisation will impact on the conceptualisation of technological innovation in this organisation.

Albert University exists in the public domain: it is funded significantly by government and is effectively accountable to multiple constituents. This university 
has experienced significant internal change over a period of 3-4 years with the notions of systematic strategic planning driving such changes. There is no doubt this approach has been driven by top management, with a mission for the whole organisation and plans for each business unit, and shared functions linked to this strategic plan. However, despite the range of plans a decision to adopt a particular innovation is not as straightforward as we might think. It certainly is an important decision that has ramifications for future educational practices and financial budgets within Albert University. In our investigation to date, it has been difficult to pinpoint when and how the decision will be made.

It is probably fair to say in the case of Albert University that there are a number of decisions that will come together to make 'the decision' on the adoption of a particular technology. The quality of the decision making is particularly important in this case because of the longer term educational and financial implications. Poorly researched decisions presented as rational and ordered often means that the organisation suffers. In this case as large diverse institutional decision making can be affected by the behaviour of the participants in many ways, as they may preserve, delay, stop a decision, and cover up the inconsistencies and the many more variations of influence. In this case it is difficult to tease out the decision making knowledge and power related decision making as the decision making process seems so unclear.

It is important to note here, the actual users of the system are not well represented in the decision making process. This approach of collecting together a particular grouping of people who in this case are from the corporate level of the organisation rather than the academic users of the system, assumes they can correctly forecast and interpret the changes for all levels, however people perceive these decisions in terms of the organisation and operation beliefs they come from. In other words, colloquially where you sit is where you stand. In relating this particular aspect back to the rational strategic management approach, this approach assumes the strategic leadership will provide the integrated leadership for decisions; in other words a balance. The problem in large, diversified organisations such as Albert University is that strategic leaders may not provide sufficient control to coordinate decision making or comprehend the entire strategic variable simultaneously. Quinn (1988) as far back as 1988 argues there are both cognitive and process limits to managers' ability to cope with these variables simultaneously.

The decision to adopt a new e-learning environment in Albert University will result more from an incremental series of decision with the construction of limited representation of decision makers from the corporate level structure to make the decision, with time imperatives imposed by the expiry of contractual arrangements and the inattention to the technology 'problem' decision earlier. This is a non-routine decision; an important one where the key players are looking around to see what the powerful are giving out about how they should act, and they are trying to do what they think is expected of them. It seems clear this big decision has been avoided for as long as possible. Senior management is now trying to involve a particular constructed group of decision makers so that if the decision goes bad the blame can be passed off or shared around. It is a culture of sidestepping decisions and trying to avoid being seen to make a mistake. It is certainly not about the users' needs or knowledge given they are largely excluded from the decision making process. 


\section{Innovation and Change: Adoption of Innovations}

Just because a new e-Learning system has been built and made available, this does not mean that it can automatically be assumed that organisations or individuals will want to adopt or to use it. Even if an organisation does adopt a new innovation, it also cannot be assumed that its employees will want to use it, and even if they have no choice and are made to use it, that they will get the most out of it. The old saying: 'You can lead a horse to water but you can't make it drink' comes to mind here.

Making any sort of change to the way things are done is always complex and can be quite difficult to achieve successfully. The successful adoption of any new technological innovation is often in doubt if people who might be prepared to support the innovator cannot be convinced to do so. Although writing of political change almost five hundred years ago Niccolò Machiavelli summed this up as follows:

"There is nothing more difficult to handle, more doubtful of success and more dangerous to carry through than initiating changes ... The innovator makes enemies of all those who prospered under the old order, and only lukewarm support is forthcoming from those who would prosper under the new. Their support is lukewarm partly from fear of their adversaries, who have the existing laws on their side, and partly because men are generally incredulous, never really trusting new things unless they have tested them by experience." (Machiavelli c1515)

Innovation can be defined as "the alteration of what is established; something newly introduced" (Oxford 1973), or "introducing new things or methods" (Macquarie Library 1981). The process of innovation involves getting new ideas accepted and new technologies adopted and used (Tatnall 2009b).

\section{Theoretical Approaches to Innovation Adoption}

To investigate the adoption of new ideas or technologies it is useful to follow one of the theories of technological innovation (Al-Hajri and Tatnall 2007). A number of approaches exist to modelling how technological innovation takes place, including the Theory of Reasoned Action (Ajzen and Fishbein 1980), the Theory of Planned Behavior (Ajzen 1991), the Technology Acceptance Model (Davis 1986), Diffusion of Innovations (Rogers 2003) and Innovation Translation (Callon 1986; Latour 1996). In particular, both the Diffusion of Innovations and the Technology Acceptance Model (TAM) are very well known and widely used approaches to theorising technological innovation. One important difference between some of these theories though is the degree to which the adoption decision is seen as completely rational, and whether provision is made for partial adoption (Tatnall 2009a). A brief discussion of several approaches to theorising adoption of innovations follows.

\subsection{The Technology Acceptance Model (TAM)}

The Technology Acceptance Model (TAM) is a theoretical model that evaluates “... the effect of system characteristics on user acceptance of computer-based information 
systems" (Davis 1986 :7). TAM assumes that a computer user normally acts rationally and uses information in a systematic manner to decide whether or not to adopt a particular technology. Davis (1986) identifies major determinants of technology acceptance and specifies a basis for causal links between the technology's perceived usefulness and perceived ease of use along with the individual's attitude towards using technology and behavioural intention to explain technology adoption (Davis 1986; Davis 1989; Davis, Bagozzi and Warshaw 1989).

\subsection{Diffusion of Innovations}

Rogers' classic work on the theory of Diffusion of Innovations (Rogers 2003) has been evolving now for over forty years. Rogers describes diffusion as: “... the process by which an innovation is communicated through certain channels over time among the members of a social system" (Rogers 2003: 5), and so a decision not to adopt an innovation relates to the rejection of the new idea. Rogers asserts that a technological innovation embodies information that has the potential to reduce uncertainty and that diffusion is thus an information exchange process amongst members of a communicating social network driven by a need to reduce uncertainty.

Rogers considers the main elements of diffusion to be: characteristics of the innovation, the communication channels through which information about the innovation pass, the passage of time, and the social system. To explain the rate of adoption of innovations Rogers suggests consideration of the following perceived characteristics of innovations: relative advantage, compatibility, complexity, trialability and observability.

\subsection{Innovation Translation: Actor-Network Theory}

Actor-Network Theory (ANT) was designed as an approach to socio-technical research that would address the need to treat the contributions of both human and non-human actors fairly and in the same way (Callon 1986). Innovation Translation (Latour 1986; Law and Callon 1988; Latour 1996), informed by Actor-Network Theory, makes use of a model of technological innovation which uses the concept of heterogeneity in a world that is full of hybrid entities (Latour 1993) containing both human and non-human elements. It notes that the process of innovation adoption is often not completely rational and that innovations are frequently not adopted in their entirety but only after 'translation' into a form that is more appropriate for use by the potential adopter. It then uses these notions in an explanation of the adoption, or nonadoption of technology (Tatnall and Davey 2007).

Callon et al. (1983) have proposed that translation involves all the strategies that an actor goes through to identify other actors and to work with or against them in order to achieve the adoption. Latour (1996) speaks of 'chains of translation' and suggests that with the translation model the initial idea hardly counts and the innovation moves only if it interests one group of actors or another. Callon (1986) suggests that the process of translation has four aspects or 'moments':

- Problematisation - the problem is re-defined (translated) in terms of solutions offered by those advocating its adoption. 
- Interessement - involves interesting an entity by coming between it and some other entity (Law 1986). It attempts to impose identities and roles defined in the problematisation on the other actors.

- Enrolment will follow through a process of coercion, seduction, or consent (Grint and Woolgar 1997), leading to the establishment of a solid, stable network of alliances.

- Mobilisation finally occurs as the proposed solution gains wider acceptance and an even larger network of absent entities is created through some actors acting as spokespersons for others.

\subsection{The Problem of Partial Adoption}

One of the difficulties faced in investigating the adoption of technological innovations is that not all innovations are adopted in the form in which they were proposed - not all are adopted without change. This raises the question of just what was adopted in each case if it was in some way different from what was proposed by its instigator. Neither TAM nor Innovation Diffusion, however, take this into account to any degree (Tatnall 2009b). Another problem with these approaches is that they assume that much of the reason for the adoption, or non-adoption, of the technology is due to characteristics of the innovation itself. This essentialist view (Grint and Woolgar 1997) leaves little room for a consideration of socio-technical issues and an investigation of why individual humans and organisations react differently to adoption of the same technology. In view of this, we will frame adoption considerations in this paper using Innovation Translation.

\section{5 e-Learning Innovation Adoption Decisions at Albert University}

We have already discussed how the strategic adoption decisions will probably be made at the university level, and the actors involved in these. Another factor that comes into it these decisions, however, is pressure from some individual academics even though they are not officially represented in the decision making process. At Albert University there are a number of academics who strongly believe in the benefits of open source software and so would favour a decision to adopt Moodle, while there are others who prefer the idea of sticking with the 'tried and true' commercial product of a large company. If these people feel strongly enough about this matter and have problematised (Callon 1986) the use of an e-learning environment in their own way then they will certainly apply pressure to the decision makers to try to enrol them (Callon 1986) into making the 'right' decision.

The first step in an actor-network analysis of the decisions by individual academics to adopt some, or all, of the e-learning package features is to identify the actors involved. Law (1987) describes an actor as any human or non-human entity that is able to make its presence individually felt by other actors. At Albert University the actors involved in this case include: course co-ordinators, subject co-ordinators, academics (teachers), sessionals, Faculty Deans and the university administration, technical staff from the Information Technology Services department, students, 
computers, screens, computer laboratories, e-learning infrastructure (including remote access) and the e-learning environment itself. Each of these actors potentially has an influence on how or whether the adoption occurs.

Firstly consider the university hierarchy; if course or subject co-ordinators, or the Faculty Dean expresses a view on this then this must be taken into account, but this much is obvious. Not so obvious is the influence of some of the non-human actors. If the e-learning infrastructure requires too much effort to come to grips with, or the elearning interface is too off-putting or non-intuitive then adoption becomes less likely.

Even if the package is adopted, however, how can partial adoption be explained? The less than friendly interface of WebCT has been one reason for only partial adoption of this package, and there are other alternatives to the e-mail it offers. The in-built testing/marking facilities are of interest to some academics but not to others and so these may or may not be adopted as they will fit less well with their problematisation of what an e-learning environment should be about. On a human level, many of us prefer human to human interactions and are reluctant to use technology in this way for teaching and learning. There is then also the concern that students will no longer bother to come to lectures. All of this means that many academics will translate the e-learning package into something that suits their own needs.

\section{Conclusion}

Adoption, implementation and use of technology, such as an e-learning system, in a large organisation such as a university has both strategic and individual adoption aspects. In this paper we have argued that the initial decision by the organisation to invest in the technology is a strategic one, best considered in terms of strategic decision making theory, while the decisions regarding individual subjects and made by individual academics can be analysed using one of the models of innovation adoption - we have used innovation translation. Whichever analysis approach is used we have argued that with its socio-technical aspects, this must be one that gives adequate weight to all human and also technology (non-human) factors.

\section{References}

Ajzen, I.: The Theory of Planned Behavior. Organizational Behavior and Human Decision Processes 50(2), 179-211 (1991)

Ajzen, I., Fishbein, M.: Understanding Attitudes and Predicting Social Behavior, London. Prentice-Hall, Englewood Cliffs (1980)

Al-Hajri, S., Tatnall, A.: Internet Technology in Omani Banks - a Case of Adoption at a Slower Rate. In: 20th Bled e-Conference - eMergence: Merging and Emerging Technologies, Processes and Institutions Bled, Slovenia, Bled e-Commerce Conference (2007)

Boxall, P., Purcell, J.: Strategy and Human Resource Management, 2nd edn. Palgrave McMillan, England (2007)

Callon, M.: Some Elements of a Sociology of Translation: Domestication of the Scallops and the Fishermen of St Brieuc Bay. Power, Action \& Belief. A New Sociology of Knowledge?, 196-229 (1986) 
Callon, M., Courtial, J.P., Turner, W.A., Bauin, S.: From Translations to Problematic Networks: An Introduction to Co-Word Analysis. Social Science Information 22(2), 191235 (1983)

Davis, F.D.: A Technology Acceptance Model for Empirically Testing New End-User Information Systems: Theory and Results. MIT, Boston (1986)

Davis, F.D.: Perceived Usefulness, Perceived Ease of Use, and User Acceptance of Information Technology. MIS Quarterly 13(3), 318-340 (1989)

Davis, F.D., Bagozzi, R., Warshaw, P.: User Acceptance of Computer Technology: A Comparison of Two Theoretical Models. Management Science 35(8), 982-1003 (1989)

Grint, K., Woolgar, S.: The Machine at Work - Technology, Work and Organisation. Polity Press, Cambridge (1997)

Hanson, D., Dowling, P.J., Hitt, M.A., Ireland, R.D., Hoskisson, R.E.: Strategic Management: Competitiveness \& Globalisation, Cengage Learning Australia, 3rd edn. (2008)

Latour, B.: The Powers of Association. Power, Action and Belief. A New Sociology of Knowledge? Sociological Review Monograph 32, 264-280 (1986)

Latour, B.: We Have Never Been Modern. Hemel Hempstead, Harvester Wheatsheaf (1993)

Latour, B.: Aramis or the Love of Technology. Harvard University Press, Cambridge (1996)

Law, J.: The Heterogeneity of Texts. Mapping the Dynamics of Science and Technology, 6783 (1986)

Law, J.: Technology and Heterogeneous Engineering: The Case of Portuguese Expansion. In: Bijker, W.E., Hughes, T.P., Pinch, T.J. (eds.) The Social Construction of Technological Systems: New Directions in the Sociology and History of Technology, pp. 111-134. MIT Press, Cambridge (1987)

Law, J., Callon, M.: Engineering and Sociology in a Military Aircraft Project: A Network Analysis of Technological Change. Social Problems 35(3), 284-297 (1988)

Machiavelli, N.: (c1515). The Prince. London, Penguin Classics edition (1995)

Macquarie Library: The Macquarie Dictionary. Macquarie Library, Sydney (1981)

Oxford: The Shorter Oxford English Dictionary. Clarendon Press, Oxford (1973)

Quinn, R.E.: Beyond Rational Management. Jossey-Bass Publishers, USA (1988)

Rogers, E.M.: Diffusion of Innovations. The Free Press, New York (2003)

Tatnall, A.: Information Systems, Technology Adoption and Innovation Translation. International Journal of Actor-Network Theory and Technological Innovation 1(1), 59-74 (2009a)

Tatnall, A.: Innovation Translation and Innovation Diffusion: A Comparison of Two Different Approaches to Theorising Technological Innovation. International Journal of ActorNetwork Theory and Technological Innovation 1(2), 67-74 (2009b)

Tatnall, A., Davey, B.: Researching the Portal. In: IRMA: Managing Worldwide Operations and Communications with Information Technology, Vancouver, Information Management Resource Association (2007) 